\title{
Diversity of Gasteromycetes in Rajasthan, India-I
}

\section{Chouhan $\mathbf{R}^{1}$ and Panwar $\mathbf{C}^{2}$}

${ }^{1}$ S.S Jain Subodh PG (Autonomous) College, Jaipur, Rajasthan, India

${ }^{2}$ Jai Narain Vyas University, Jodhpur, Rajasthan, India

Chouhan R, Panwar C 2021 - Diversity of Gasteromycetes in Rajasthan, India-I. Studies in Fungi 6(1), 175-187, Doi 10.5943/sif/6/1/11

\begin{abstract}
In this paper, taxonomic descriptions of eight members of Gasteromycetes belonging to Montagnea, Phellorinia, Podaxis and Tulostoma are given. Among four Podaxis species described, Podaxis africana, P. beringamensis and P. saharianus are new records for India. Phellorinia herculeana subsp. herculeana and $P$. herculeana subsp. strobilina are also described herein while $P$. herculeana subsp. strobilina is a new record for India. Taxonomic descriptions of Montagnea haussknechtii and Tulostoma brumale reveal new insights into the rare species of Gasteromycetes confined to arid and semi-arid areas worldwide while $M$. haussknechtii is a new record for India.
\end{abstract}

Keywords - edible mushrooms - Montagnea - Phellorinia - Podaxis - Tulostoma

\section{Introduction}

Rajasthan is the largest state of India. It lies at $27.0238^{\circ} \mathrm{N}, 74.2179^{\circ} \mathrm{E}$ in the Northern Hemisphere with extreme arid and semi-arid climatic conditions. The mushroom flora of this location is endemic (Chouhan et al. 2010). This is especially true for members of the subgroup Gasteromycetes which are susceptible to harsh conditions of the desert. Mycofloristic surveys carried out after the meagre rainfall have revealed the appearance of different macrofungi in diverse habitats, on a variety of substrates and that are able to survive desiccating environmental conditions.

Podaxis has been reported by a variety of researchers to be able to grow in dry and sandy or in grassy habitats by various workers namely Linnaeus (1771), Bottomley (1948), De Villiers et al. (1989), Priest \& Lenz (1999) and Conlon et al. (2016). To date, 44 species of Podaxis have been recorded and described (Conlon et al. 2016).

In the present study, four species namely Podaxis pistillaris, $P$. africana, $P$. saharianus and $P$. beringamensis have been reported from Rajasthan, India. Podaxis africana, P. saharianus and $P$. beringamensis are newly recorded species for India.

Phellorinia is another commonly found edible gasteromycetes fungus that is found in the sandy and grassy habitats after monsoon rains. Two species, namely, Phellorinia herculeana subsp. herculeana and $P$. herculeana subsp. strobilina have been described herein.

Phellorinia herculeana subsp. herculeana (= Phellorinia inquinans) was reported earlier by Doshi \& Sharma (1997) and Sharma et al. (2015), but P. herculeana subsp. strobilina is a new record for India.

Montagnea haussknechtii is a rare fungus (Baseia \& Galvao2002) and there has long been a taxonomic debate over it is an agaricoid or gasteroid fungus (Singer 1986). However, it has been reported for the first time to be from India. 
Tulostoma brumale belongs to the gasteromycete flora of Rajasthan, India and has been documented by Doshi \& Sharma (1997) to be from Rajasthan. It has been described taxonomically herein.

\section{Materials \& methods}

Mushrooms were collected from various localities of Rajasthan, particularly in arid areas after the meagre rainfall. Notable, Rajasthan has been divided into ten agro-climatic zones. The areas surveyed and reported for Gasteromycetes herein include IA, (Barmer, Bikaner, Jaisalmer, parts of Churu and Jodhpur), IC (Jaisalmer, Bikaner and parts of Churu) and IIb (Jalore, Pali and parts of Sirohi and Jodhpur) shown in Fig. 1.

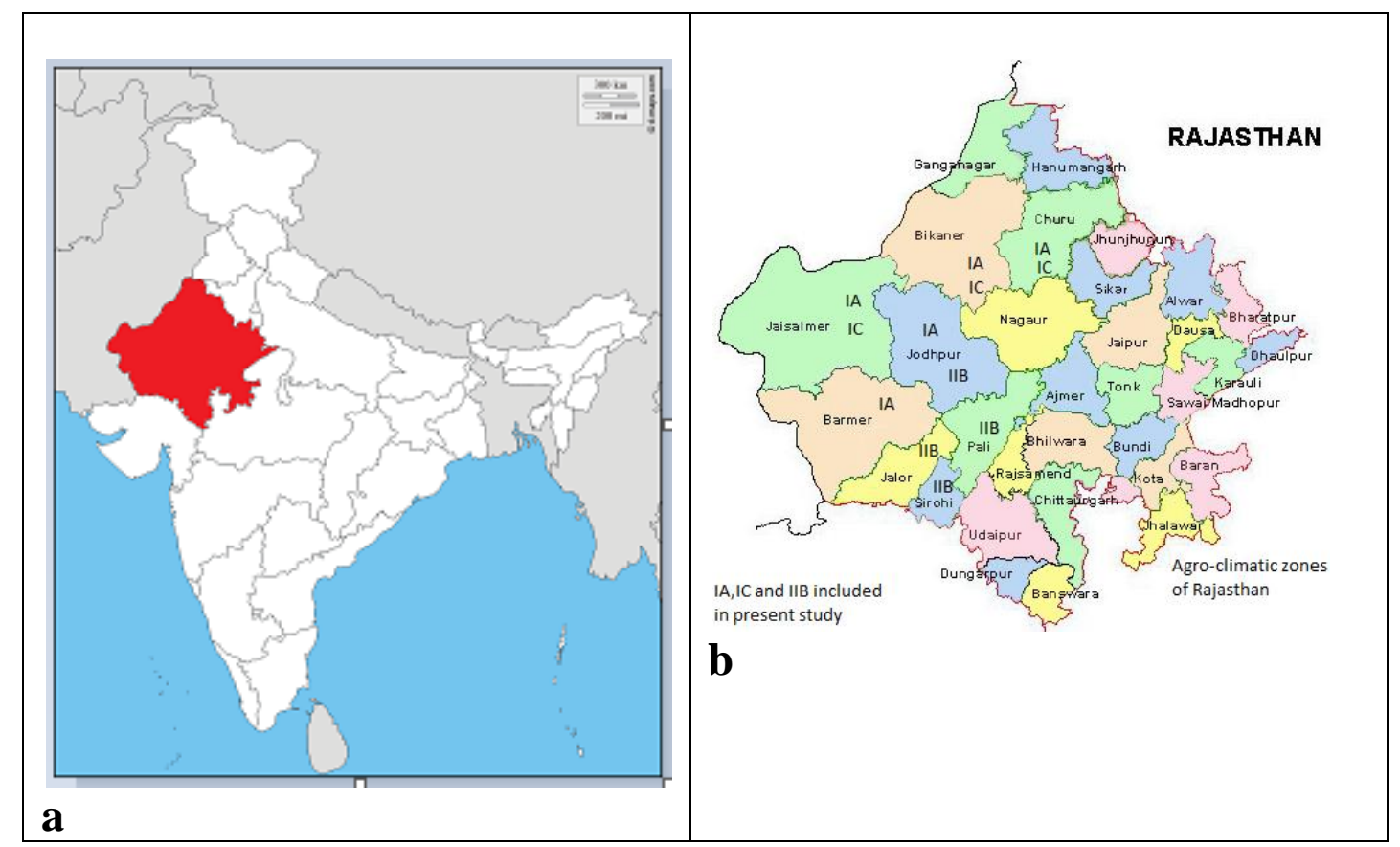

Fig. 1 - a Map of India showing the State Rajasthan. b Agroclimatic Zones of Rajasthan Zones IA, IC and IIB showing the districts in the present surveys.

Field notes were prepared with regard to various characteristics such as morphology, size, shape, colour, substrate of growth, and climatic and soil characteristics. Ethanobotanical information and local uses were also noted along with the date and time of collection. Field photography was done for all the mushrooms in their natural habitat. The specimens were carefully dug out and gently cleaned with the use of a brush to remove any soil particles and litter. The specimens were then placed in small cardboard boxes or paper bags after assigning them a specimen number and a label containing relevant information. Further, macroscopic and microscopic observations were made in the laboratory using identification keys and monographs. All the collections have been deposited under JNV/Mycl in the Herbarium of Botany Department, Jai Narain Vyas University, Jodhpur, Rajasthan (India). During the present investigation, authentic names of the investigated taxa have been assigned according to MycoBank (www.mycobank.org). Facesoffungi numbers were registered as per Jayasiri et al. (2015). All photographs are copyright of the authors Reenu Chouhan and Charu Panwar.

\section{Results}

\section{Taxonomic Study}

Phellorinia herculeana subsp. herculeana (Pers.) Kreisel, 1961 (Pers.) Kreisel, Česká Mykol. 
Index Fungorum Number: IF427863; Facesoffungi number: FoF09746

Medium sized puffballs were found solitary or in groups on sand dunes and in sandy places. Fruiting body $-7-8 \mathrm{~cm}$ in diameter, sporophore consisting of a big round to globose head which is the spore- bearing closed structure. Peridium - white, covered with large imbricate scales. Endoperidium - thin and finally breaking up across the flattened apical surface to expose the gleba. Stipe $-7-13 \mathrm{~cm} \times 1.5-4.5 \mathrm{~cm}$, solid, fleshy. Fibrous, white, equal but slightly swollen towards the base. Spores - 6-7 $\mu \mathrm{m}$, globose, finely verrucose or covered with fine, closely arranged echinulations.

Ecology and distribution - Phellorinia herculeana subsp. herculeana (= Phellorinia inquinans) was reported earlier by Doshi \& Sharma (1997) and Sharma et al. (2015). According to Bohra et al. (2001), this species is distributed in western Rajasthan (India). It has been reported by various researchers from different regions of the world including Pakistan (Ahmad 1952), Australia (Fuhrer 2005, Williams \& Woinarski 1997), Spain and Yemen (Kreisel \& Fatimi 2004).

$P$. herculeana subsp. herculeana grows abundantly in rainy season on sand dunes. Soil characteristics of natural growing sites of this species have been studied by Manikandan et al. (2011). Accordingly, it appeared in infertile, sandy soils in which organic matter content was reported to be very poor but needed better aeration and well-drained soil conditions.

Specimens examined - JNV/Mycl/150 on 30 July 2017 in zone IA, IC and IIb of survey area on sand dunes and in sandy places by Reenu Chouhan, $25^{\circ} 45^{\prime} 0.00^{\prime \prime} \mathrm{N} 71^{\circ} 22^{\prime} 48.00^{\prime \prime E}$ Barmer, elevation: $227 \mathrm{~m}(745 \mathrm{ft}), 28^{\circ} 01^{\prime} 3.43^{\prime \prime N} 73^{\circ} 18^{\prime} 53.82^{\prime \prime E}$ Bikaner, elevation: $242 \mathrm{~m}(794 \mathrm{ft})$

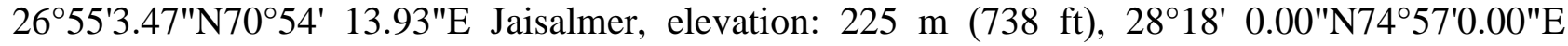
Churu, elevation: $292 \mathrm{~m}$ (958 ft), 26 $16^{\circ} 6.28^{\prime \prime N} 73^{\circ} 00^{\prime} 21.38^{\prime \prime E ~ J o d h p u r, ~ e l e v a t i o n: ~} 231 \mathrm{~m}$ (758 ft) $25^{\circ} 20^{\prime} 44.09^{\prime \prime N} 72^{\circ} 36 ' 56.12^{\prime \prime E}$ Jalore, elevation: $178 \mathrm{~m}(584 \mathrm{ft}), 25^{\circ} 46^{\prime} 12.00^{\prime \prime N} 73^{\circ} 19^{\prime} 48.00^{\prime \prime E}$ Pali,

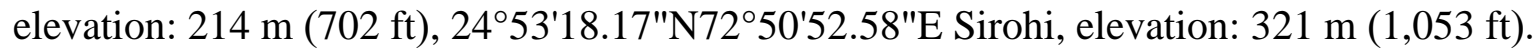

Note - Phellorinia herculeana subsp. herculeana commonly known as 'marukhumbhi' among the local people is an edible gasteroid fungus growing in the semi-arid and arid areas of Rajasthan Doshi \& Sharma (1997). The fruiting body of this mushroom possesses a smooth round globose head and is called 'scaly' form of Phellorinia in comparison to the 'warty' appearance of P. herculeana subsp. strobilina (Bottomley 1948). It appears individually or in groups during the rainy season particularly after flashes of lightning.

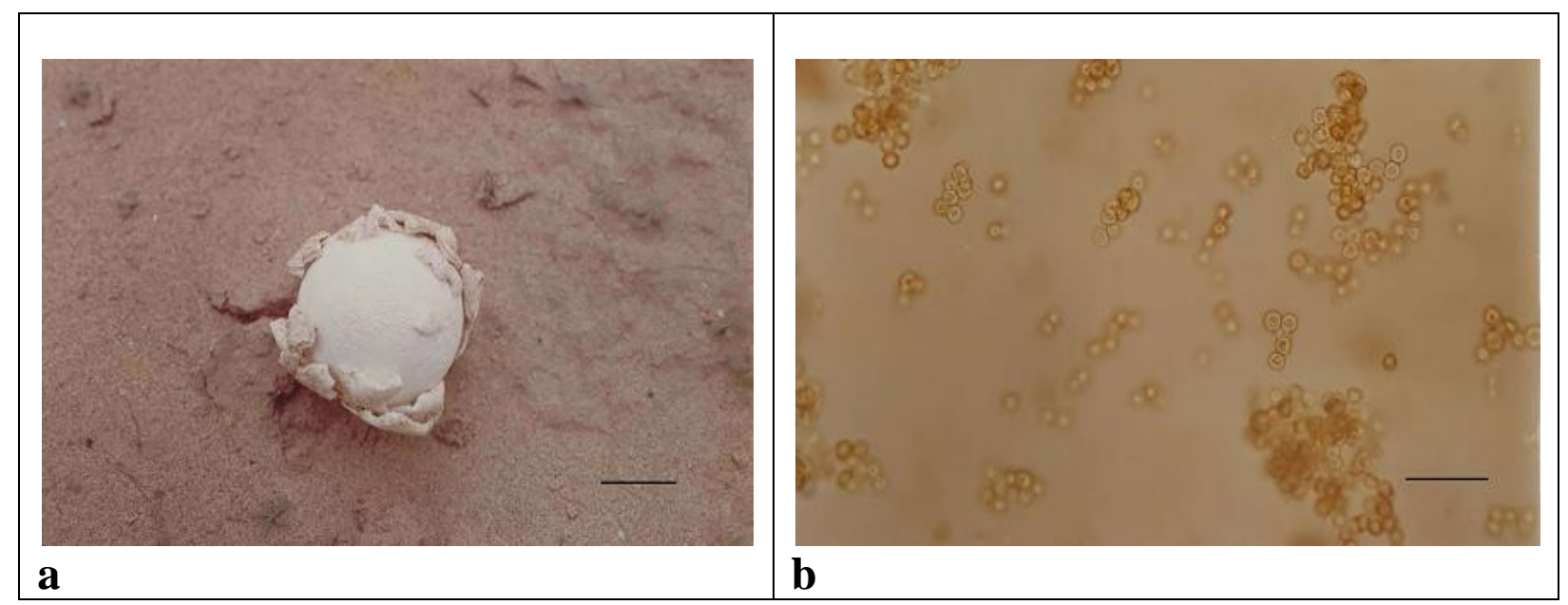

Fig. 2 - a Fruiting body of Phellorinia herculeana subsp. herculeana on sand dunes in natural conditions. $b$ Spores. Scale bars: $a=5 \mathrm{~cm}, \mathrm{~b}=20 \mu \mathrm{m}$.

Phellorinia herculeana subsp. strobilina (Kalchbr.,) Dring \& Rayss, Israel J. Bot. 12: 176(1964)

Index Fungorum Number: IF349974; Facesoffungi number: FoF09747 
Fruiting body -9-12 cm high, creamish-white, stipitate, coarsely scaly, typically shaped like a wine glass. Stipe - solid and woody, the base of the stipe typically enlarged into a hardened mass of soil and mycelium resembling a sclerotium and sometimes giving rise to two or three fruiting bodies. Peridium - coarsely scaly with large imbricate scales that persist longer where the stipe expands to form the spore case. Endoperidium - thin and finally breaking up across the flattened apical surface to expose the rusty-cinnamon gleba. Gleba - rusty-cinnamon, capitilial threads thickwalled, pale ochraceous, rarely septate. Spores $-5-7 \times 4.5-6.0 \mu \mathrm{m}$, globose to sub-globose, finely verrucose.

Ecology and distribution - Phellorinia herculeana subsp. strobilina has been reported on dry sandy soil in arid and semi-arid areas by Dring (1964) and Dring \& Rayner (1967) from Africa and Zimbabwe by Sharp \& Piearce (1999).

Specimens examined - JNV/Mycl/140 on 28 July 2017 in zone II B of survey area by Charu Panwar growing in soil amongst grasses. $26^{\circ} 16^{\prime} 6.28^{\prime \prime N} 73^{\circ} 00^{\prime} 21.38^{\prime \prime E}$ Jodhpur, elevation: $231 \mathrm{~m}$ (758 $\mathrm{ft}), 25^{\circ} 20^{\prime} 44.09^{\prime \prime N} 72^{\circ} 36^{\prime} 56.12^{\prime \prime E}$ Jalore, elevation: $178 \mathrm{~m}(584 \mathrm{ft}), 25^{\circ} 46^{\prime} 12.00^{\prime \prime N} 73^{\circ} 19^{\prime} 48.00^{\prime \prime} \mathrm{E}$ Pali, 245' 53 '18.17"N7250' 52.58"E Sirohi, elevation: $321 \mathrm{~m}(1,053 \mathrm{ft})$.

Note - Phellorinia herculeana subsp. strobilina differs from $P$. herculeana subsp. herculeana in possessing large, thick, pyramidal, coarse, persistent scales of the exoperidium that are larger and more prominently developed in the apical portion. Gleba and spores are the same as in $P$. herculeana subsp. herculeana. Specimens attained a length of $18-20 \mathrm{~cm}$, with a stipe that is 6-7 $\mathrm{cm}$ thick in diameter. $P$. herculeana has been reported by Sharma et al. (2015) to be from Jaisalmer, Rajasthan but $P$. herculeana subsp. strobilina is a newly recorded species for India.

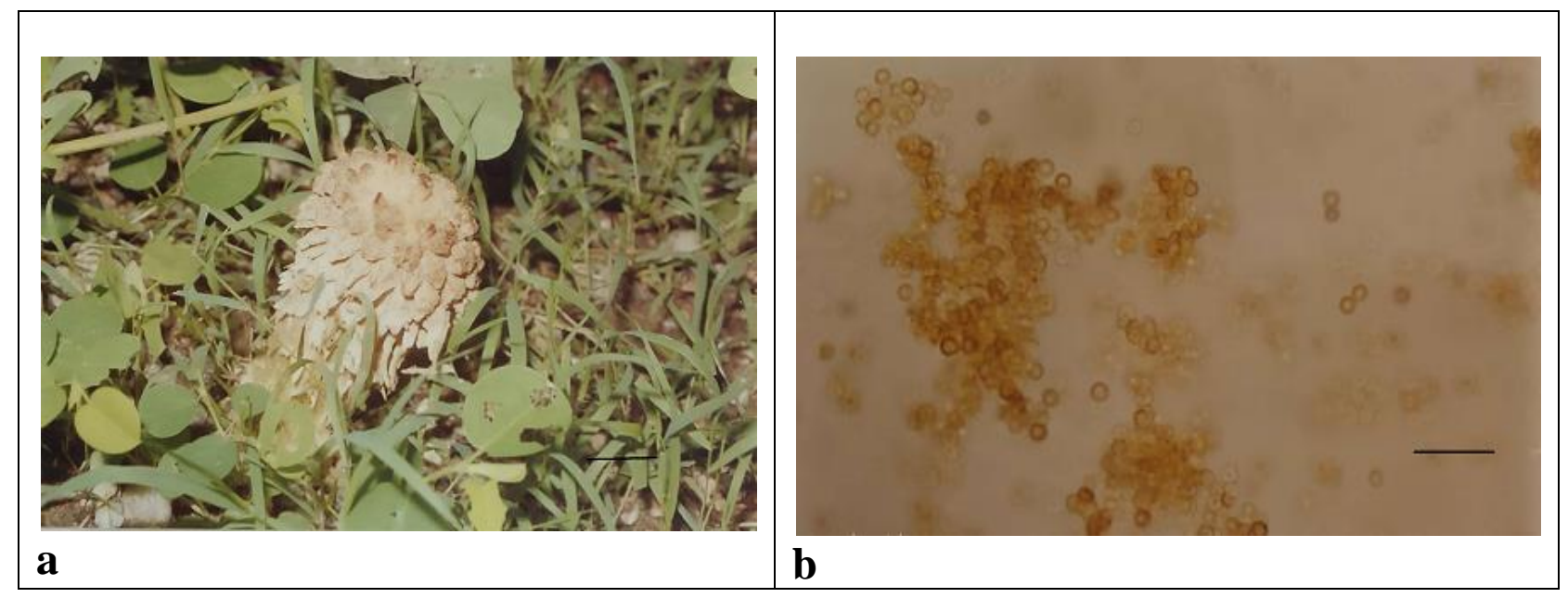

Fig. 3 - a Fruiting body of Phellorinia herculeana subsp. strobilina growing on grassy habitats in natural conditions. $b$ Spores. Scale bar: $a=5 \mathrm{~cm}, b=20 \mu \mathrm{m}$.

Podaxis africana De Villiers, Eicker \& Westhuizen S. Afr. J. Bot. 55(2): 160(1989)

Fig. 4

Index Fungorum Number: IF125143; Facesoffungi number: FoF09748

Fruiting body - stipitate, $16.0-25.0 \mathrm{~cm}$ tall, dry, indehiscent at maturity. Stipe - cylindrical to subcylindrical or flattened, $8.0-9.5 \times 0.7-2.0 \mathrm{~cm}$, broad at the base to form a small bulb of intermingled sand and hyphae. Peridium - ellipsoidal, subcylindrical or nearly fusiform, 5.5-10.5 $\times 2.5-4.0 \mathrm{~cm}$ yellowish white with lower margin incurved at maturity and scaly. Exoperidium creamish-white. Endoperidium - yellowish-brown, dehiscing longitudinally at maturity, more or less fragile when dry. Gleba - brownish-black. Spores $-6.0-6.5 \times 7.0-7.5 \mu \mathrm{m}$ fuscous black to umber, globose, subglobose to ovoid, with a short apiculus and prominent distal germ pore.

Ecology and distribution - De Villiers et al. (1989) reported Podaxis africana from termite heaps in South Africa. According to Conlon et al. (2016), it is unknown whether the termites feed on the fungus or that Podaxis uses the favorable conditions and concentrated nutrients within the nest to 
grow as a commensal without affecting the termites, or as a parasite growing inside the nest to the detriment of the colony.

Specimens examined - JNV/Mycl/162, 20 August 2018 in zone IA and IC on sand dunes by Reenu Chouhan. 25 $45^{\prime} 0.00^{\prime \prime N} 71^{\circ} 22^{\prime} 48.00^{\prime \prime E}$ Barmer, elevation: $227 \mathrm{~m}(745 \mathrm{ft}), 28^{\circ} 01^{\prime} 3.43^{\prime \prime} \mathrm{N}$ 7318'53.82"E Bikaner, elevation: $242 \mathrm{~m}$ (794 ft), 26 55'3.47"N7054'13.93"E Jaisalmer, elevation: $225 \mathrm{~m}$ (738 ft), 2818'0.00"N7457'0.00"E Churu, elevation: $292 \mathrm{~m}$ (958 ft).

Note - The description of the above genera resembles that of De Villiers et al. (1989) from Africa in terms of the dimensions of the fruiting body, characteristics and colour of the endoperidium, exoperidium and spores. This was the first report of this species from India.

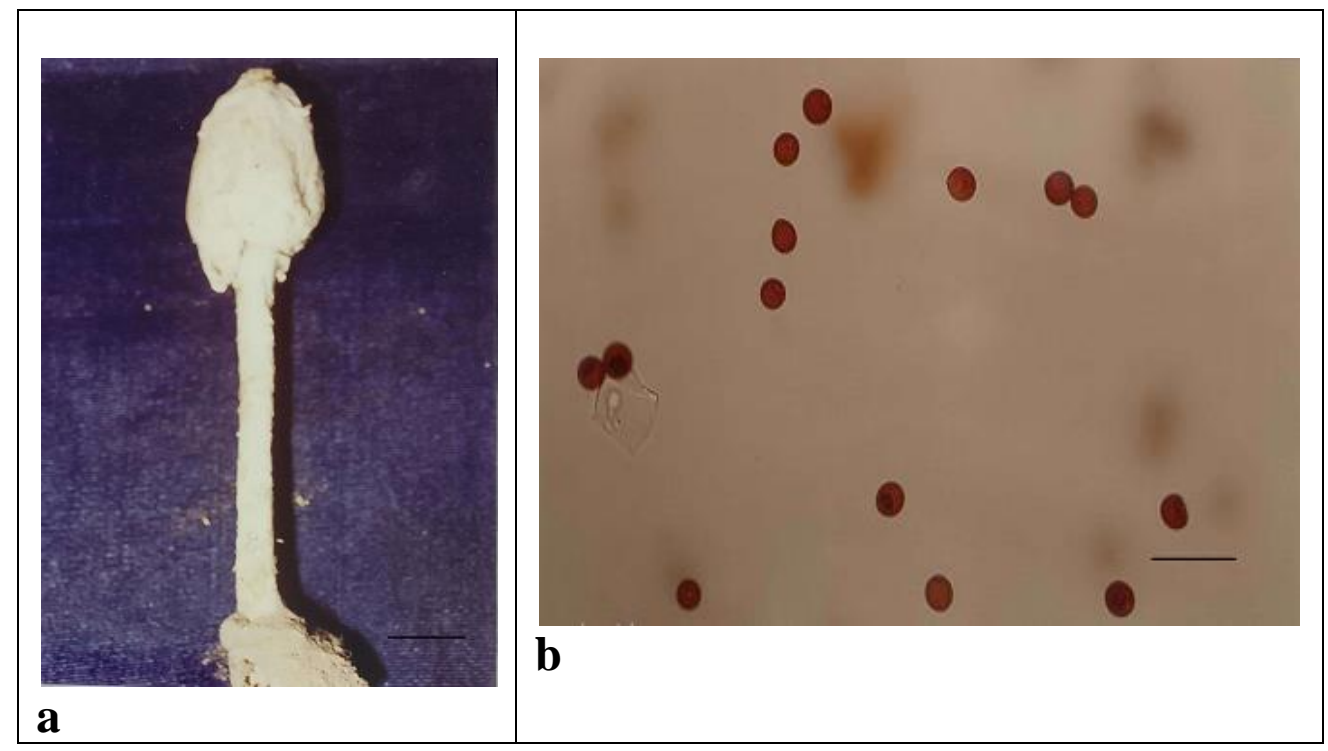

Fig. 4 - a Fruiting body of Podaxis africana. $b$ Spores. Scale bars: $a=5 \mathrm{~cm}, \mathrm{~b}=20 \mu \mathrm{m}$.

Podaxis beringamensis M.J. Priest et M. Lenz, Systematic Botany 12: 109-116 (1999)

Index Fungorum Number: IF19269; Facesoffungi number: FoF09749

Fruiting body - stipitate, 15-35 cm in height, dull-white in colour, dry, scaly and perhaps the tallest specimen collected during and present surveys. Peridium - up to $15 \mathrm{~cm}$ high and $4.5 \mathrm{~cm}$ in diameter, sub-conical in shape with an acute apex. Exoperidium - scaly and flaking to expose the endoperidium. Endoperidium - pale to dark brown, smooth to longitudinally lacerate and exposing the gleba. Stipe - straight to curved, sometimes twisted, smooth, white to brown, up to $5 \mathrm{~cm}$ wide at the base, bulbous and narrowing at the apex. Gleba ochraceous to deep brown to black at maturity. Spores - oval toelliptical with a truncate base, smooth, yellow when immature, becoming deep reddish brown at maturity, 5.0-6.0 × 7.0-7.5 $\mu \mathrm{m}$, double walled with an apical pore.

Ecology and distribution - This species was reported to be occurring on termite mounds in Australia by Priest \& Lenz (1999). Gay (1970) reported the termite mounds as an ideal habitat for $P$. beringamensis. Accordingly, the walls of the mounds are usually composed of semi-digested plant material, soil and other organic matter and the relative humidity within termite mounds is near saturation with stable temperatures.

Specimens examined - JNV/Mycl/163, 21 August 2018 in Zone IA and IIB on sandy soil associated with termite nests collected by Sanjay Panwar. $25^{\circ} 45^{\prime} 0.00 " \mathrm{~N} 71^{\circ} 22^{\prime} 48.00^{\prime \prime} \mathrm{E}$ Barmer, elevation: $227 \mathrm{~m}(745 \mathrm{ft}), 2^{\circ} 01^{\prime} 3.43^{\prime \prime N} 73^{\circ} 18^{\prime} 53.82^{\prime \prime E}$ Bikaner, elevation: $242 \mathrm{~m}$ (794 ft)

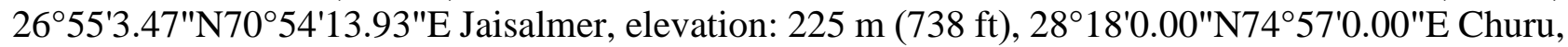
elevation: $292 \mathrm{~m}(958 \mathrm{ft}), 2^{\circ} 16^{\prime} 6.28^{\prime \prime N} 73^{\circ} 00^{\prime} 21.38^{\prime \prime E}$ Jodhpur, elevation: $231 \mathrm{~m}$ (758 ft), $25^{\circ} 20^{\prime} 44.09^{\prime \prime N} 72^{\circ} 36^{\prime} 56.12^{\prime \prime E ~ J a l o r e, ~ e l e v a t i o n: ~} 178 \mathrm{~m}(584 \mathrm{ft}), 25^{\circ} 46^{\prime} 12.00 " \mathrm{~N} 73^{\circ} 19^{\prime} 48.00^{\prime \prime E}$ Pali, elevation: $214 \mathrm{~m}$ (702 ft), 2453'18.17"N7250'52.58"E Sirohi, elevation: $321 \mathrm{~m}$ (1,053 ft).

Note - The description of the above genera resembles that of Priest \& Lenz (1999) from Australia in terms of the dimensions of the fruiting body, characteristics and colour of endo and 
exoperidium except for minor differences in the size of the spores. This species is distinguished by its elliptical spores and tall stature. This species is a new record for India.

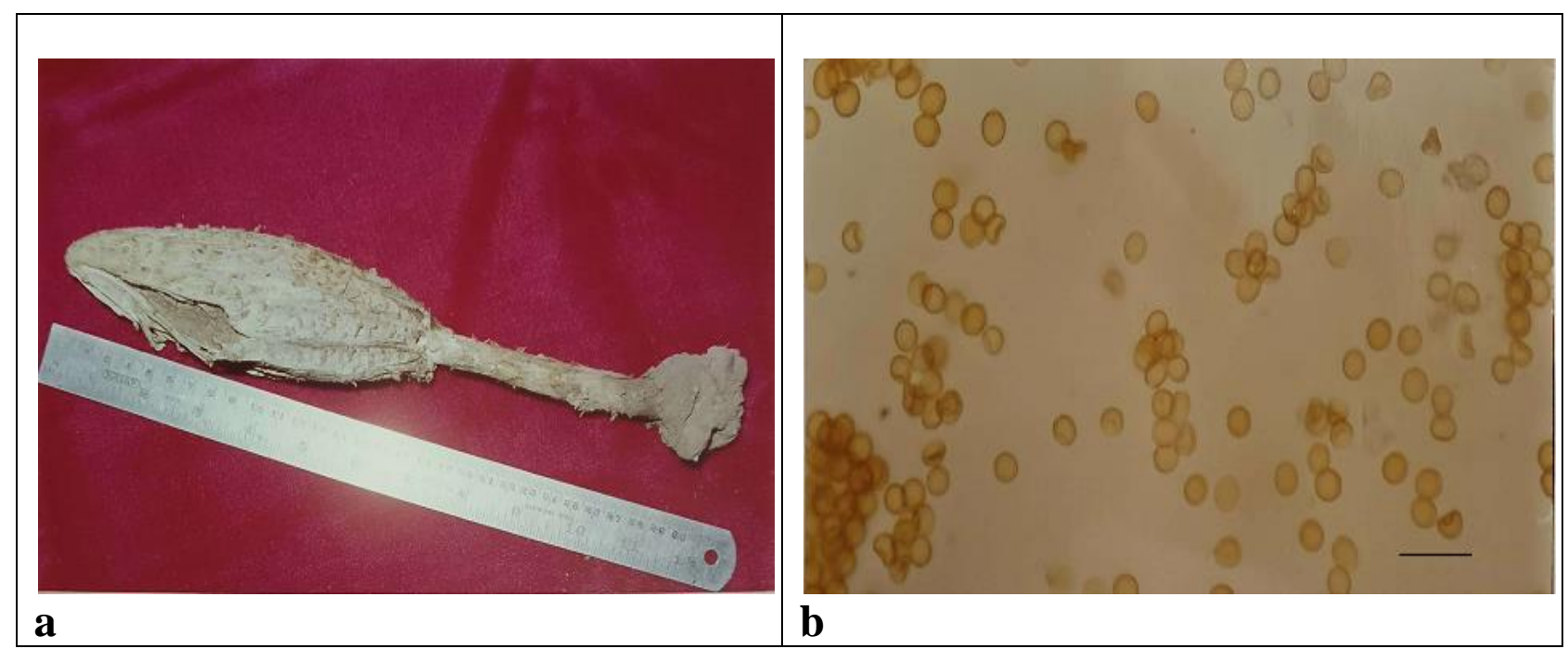

Fig. 5 - a Fruiting body of Podaxis beringamensis. b Spores. Scale bar: $b=20 \mu \mathrm{m}$.

Podaxis pistillaris (L.) Fr., Systema Myco. 3: 63(1829)

Fig. 6

Index Fungorum Number: IF356687; Facesoffungi number: FoF09293

Fruiting Body $-8-15 \mathrm{~cm}$ in height, white to cream, centrally stipitate, solid when young, papery and powdery at maturity. Stipe - central, $5-10 \mathrm{~cm}$ long, $1.5-2.0 \mathrm{~cm}$ in diameter, abruptly bulbous at the base, sometimes twisted concolorous with the peridium and fibrillose to scaly. Peridium - 4-10 $\mathrm{cm}$ high, 2.5-5.0 cm wide, cylindrical and white. Exoperidium - white when immature and scaly. Endoperidium - olive to brown to blackish- brown at maturity. Gleba - white when young, which changes to yellowish, then reddish-brown and finally black, and powdery at the time of dispersal of spores. Spores - with wide range in size from specimens collected from different localities, size ranging from 4.0-7.5 $\times 7.0-9.5 \mu \mathrm{m}$, globose, subglobose to broadly ellipsoid, smooth, variable in colour from light brown to dark fuscous brown, double walled, outer wall thick, with a distinct germ pore.

Ecology and distribution - Podaxis pistillaris has been known to occur on sandy soils in various regions of the world and has been reported from Southern Iraq (Muhsin et al. 2012), Brazil (Baseia \& Galvao 2002), Mexico (Martin et al. 2005), Saudi Arabia (Hashem \& Al-Rahmah 1993) and Yemen (Al-Fatimi et al. 2006). In India, Podaxis pistillaris has been reported by Ahmad (1939), Hennings (1901), Thind \& Thind (1982), Doshi \& Sharma (1997), Patel \& Tiwari (2012), Patil et al. (1995) and Mridu \& Atri (2015).

Specimens examined - JNV/Mycl/160 and 161 on 25 August 2018 in Zones IA, IC and IIB on sandy dunes of the Thar Desert of Jaisalmer and amongst grasses on well drained sandy soil, collected by Charu Panwar. 25 $45^{\prime} 0.00^{\prime \prime} \mathrm{N} 71^{\circ} 22^{\prime} 48.00^{\prime \prime E}$ Barmer, elevation: $227 \mathrm{~m}$ (745 ft),

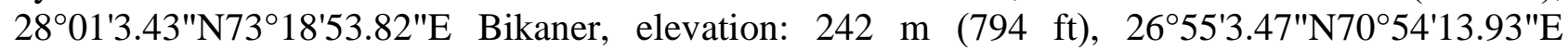
Jaisalmer, elevation: $225 \mathrm{~m}$ (738 ft), 28 $18^{\prime} 0.00^{\prime \prime N 74}{ }^{\circ} 57^{\prime} 0.00^{\prime \prime E}$ Churu, elevation: $292 \mathrm{~m}$ (958 ft), $26^{\circ} 16^{\prime} 6.28^{\prime \prime} \mathrm{N} 73^{\circ} 00^{\prime} 21.38^{\prime \prime} \mathrm{E}$ Jodhpur, elevation: $231 \mathrm{~m}$ (758 ft), $25^{\circ} 20^{\prime} 44.09^{\prime \prime N 72} 366^{\prime} 56.12^{\prime \prime E}$ Jalore, elevation: $178 \mathrm{~m}(584 \mathrm{ft}), 2^{\circ} 46^{\prime} 12.00^{\prime \prime N} 73^{\circ} 19^{\prime} 48.00^{\prime \prime E}$ Pali, elevation: $214 \mathrm{~m}$ (702 ft), 245' 18.17 "N72 50 '52.58"E Sirohi, elevation: $321 \mathrm{~m}$ (1,053 ft).

Note - There has been much controversy with regard to the taxonomy and the reduction of Podaxis specimens to a single species. Taxonomic research conducted by Morse (1933) on North American Gasteromycetes, has led to a reduction of 32 species of Podaxis under a single name, Podaxis pistillaris. This outcome has not been accepted by various researchers like Heim (1939, 1977) but has been widely adopted by Bottomley (1948) and Doidge (1950). The taxonomy of Podaxis has been reviewed by B.H. Conlon et al. (2016). According to him, there are 44 recognized 
species named in the Index Fungorum but the vast majority of studies and fungarium specimens still refer to $P$. pistillaris.

Antimicrobial and antifungal activities of Podaxis pistillaris have already been explored by the authors earlier (Panwar \& Purohit 2002, Panwar et al. 2002), taxonomic descriptions of all the species have been given in this communication.

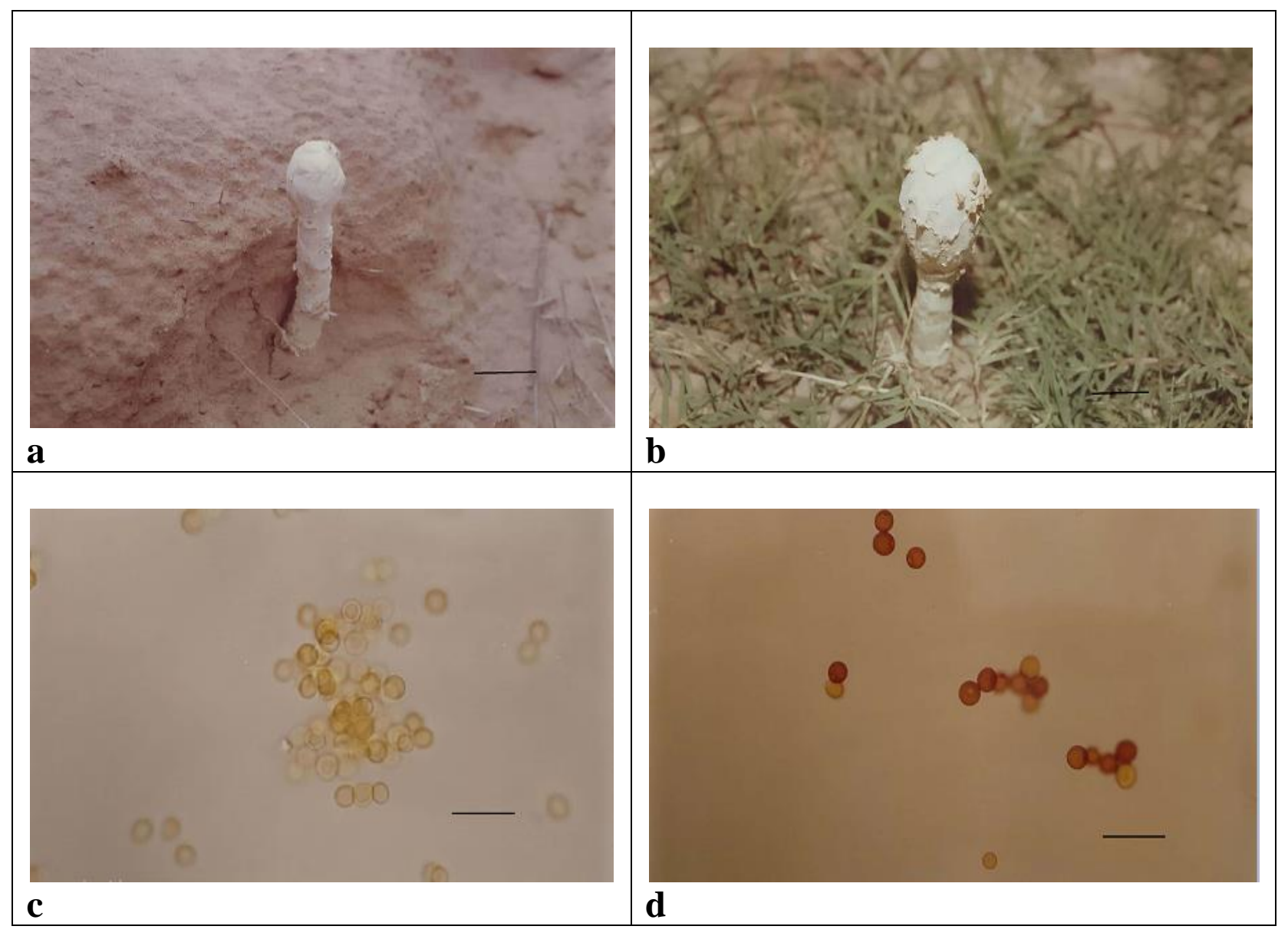

Fig. 6 - a, b Fruiting bodies of Podaxis pistillaris growing on sand dunes and in grasslands in natural conditions. c, d Spores of Podaxis pistillaris. Scale bars: $\mathrm{a}, \mathrm{b}=5 \mathrm{~cm}, \mathrm{c}, \mathrm{d}=20 \mu \mathrm{m}$.

Podaxis saharianus G. Moreno \& Mornand Cryptogamie Mycologie 18: 247-254(1997)

Fig. 7

Index Fungorum Number: IF19269; Facesoffungi number: FoF09750

Fruiting body - stipitate, bulbous, 12.0-16.0 cm tall, dry, bulb and stipe diffentiated only by a difference of 1.0-1.5 mm in dimensions of diameter. Stipe - cylindrical to subcylindrical to flattened, 7.5-10.5 $\times 1.5-3.5 \mathrm{~cm}$, broad at the baseto form a small bulb of intermingled sand and hyphae. Peridium - ellipsoidal, subcylindrical or fusiform, $5.5-8.5 \times 2.5-4.0 \mathrm{~cm}$ creamish white, uniformly scaly. Exoperidium - creamish-white. Endoperidium - deep reddish-brown, dehiscing longitudinally at maturity and fragile when dry. Gleba - deep reddish- brown only at the topmost part, base of gleba near stipe portion is white to cream. Spores $-10.0-12.0 \times 8.0-10.0 \mu \mathrm{m}$, deep red to fuscous reddish brown, thick but smooth walled, ovoid to ellipsoid possessing a short apiculus, with prominent distal germ pore.

Ecology and distribution - Moreno \& Mornand (1997) reported Podaxis saharianus from xerophytic habitats in Morocco for the first time. This hardy species flourishes well in a nutrientpoor environment, well drained sandy soil after rainfall and has a shelf life of three to five days.

Specimens examined - JNV/Mycl/164, 20 August 2018 in zone IC on sand dunes, collected by

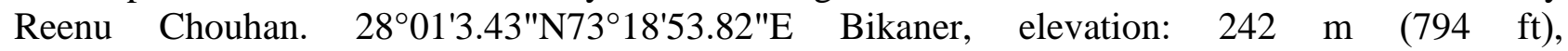




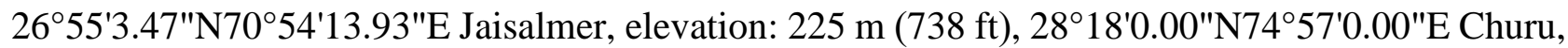
elevation: $292 \mathrm{~m}(958 \mathrm{ft})$.

Note - Moreno \& Mornand (1997) reported different specimens of Podaxis with larger spores in comparison to other species of Podaxis. Furthermore, these specimens display a much thinner stipe making the cap appear more bulbous in the deserts of Morocco and Iraq and they classified them as Podaxis saharianus. According to the phylogenetic analysis of the Podaxis specimens obtained from South Africa by Conlon et al. (2016), specimens were similar to P. saharianus with the large spores as has been reported in the findings of the Clade $\mathrm{C}$ of that research. According to Conlon et al. (2019), an adaptation was stated to maximize reproductive success and minimize the cost of growth in a nutrient-poor environment as the fungus would need more resources to establish itself in sandy environments when compared to the nutrient-rich termite mounds in grassy areas. Additionally, the thick walls would help to prevent desiccation. According to the present findings, it was concluded that the desert specimens found in sandy habitats form a monophyletic group. This was notable, different from other Podaxis specimens with termite associations and it has been reported here as P. saharianus.

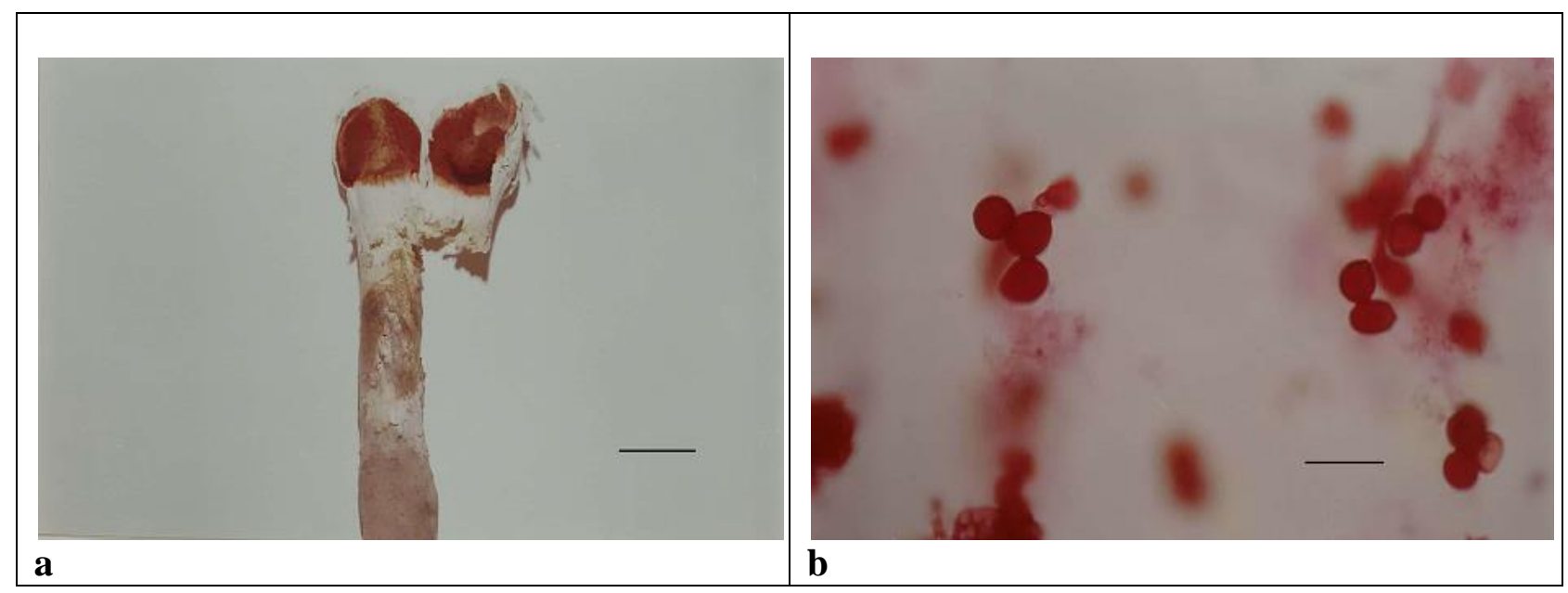

Fig. 7 - a Fruiting body of Podaxis saharianus collected from sand dunes. b Spores. Scale bars: a = $5 \mathrm{~cm}, \mathrm{~b}=20 \mu \mathrm{m}$.

Montagnea haussknechtii Rab., Sitzungsber. Naturw Ges. 'Isis' Dresden 8, 1870

Fig. 8 Index Fungorum Number: IF180658; Facesoffungi number: FoF09751

Fruiting Body - consisting of pileus, lamellae and centrally stipitate with a hard-woody stipe. Pileus $-1.5-3.5 \mathrm{~cm}$ in diameter, usually truncate campanulate rarely becoming convex or applanate. The flesh of pileus reduced to a delicate membrane stretched over the lamellae, but thicker at the centre. At an early stage splitting radially near the disc but then reduced completely toward the margin of the cap. The gills then appear free and hang vertically downward attached to the disc. Colour range from grayish-white at the disc, where the surface may disrupt into small ad pressed fibrillose scales, or appear ruptured radially to give a cog-wheel effect. Then, finally pileus becomes black exposing the lamellae. Lamellae - black, very crowded and radially oriented. Stipe - 7.0-10.5 $\times 0.5-1.0 \mathrm{~cm}$, woody, white to cream, longitudinally wrinkled with a fibrillose surface or coarse squarrose scales, equal, or more tapered towards the base with a small inconspicuous, fibrillose volva and displaying a fringed margin. Hymenium - in dried specimens comprising of a uniform brown honeycomb-like surface of collapsed and strongly agglutinated 4-spored basidia. Spores $-5.5-8.0 \times$ $3.0-4.5 \mu \mathrm{m}$, appearing black in the mass, but brown under the microscope. Elliptic, angular and diamond-shaped or ovoid in shape with a slightly thickened wall and an oblique germpore.

Ecology and Distribution - The ecology of Montagnea haussknechtii has been studied by (Jacobson 1996) on decomposing dung in the dry sand dunes of the Namib Desert (South Africa) 
which is one of the driest places on earth. Later, this xerophilic species was recorded from Brazil on sandy soil by Baseia \& Milanez (2002).

Specimens examined - JNV/Mycl/184 on 20 July 2018 in zone IC only in sandy soil, collected by Reenu Chouhan. 28 01'3.43"N73'18'53.82"E Bikaner, elevation: $242 \mathrm{~m}$ (794 ft),

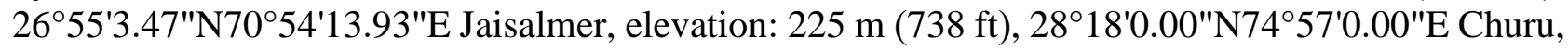
elevation: $292 \mathrm{~m}(958 \mathrm{ft})$.

Note - The taxonomic description of this species has been given by Reid \& Eicker (1991) from South Africa. Montagnea haussknechtii has been recorded during intense forays of dry areas of Jaisalmer District. The woody nature of the fungal tissue especially in the stipe helps to withstand dessication and it is not easily eroded by the force of dry winds. Moreover, they contain agglutinated 4-spored basidia which ensure effective dispersal of spores in these sandy habitats. Hence, these fungi are interesting desert survival- adapted species that have evolved several adaptations. This has helped them to survive under these harsh environmental conditions (Jacobson 1996).

There are controversies in the taxonomic position of Montagnea as Singer (1986) observed that the affinities of this new family Montagneaceae lie with Coprinaceae in the Agaricales. However, according to his writings "If there is such a thing as a Gasteromycete, Montagnea is one of them." Furthermore, according to Vilgalys et al. (1993), there is evidence from the rDNA sequences data to support the long-held hypothesis for other close relationships among secotioid, false truffles, and agaric forms such as the shaggy mane mushroom, Coprinus comatus and the gasteroid forms of Montagnea and Podaxis.

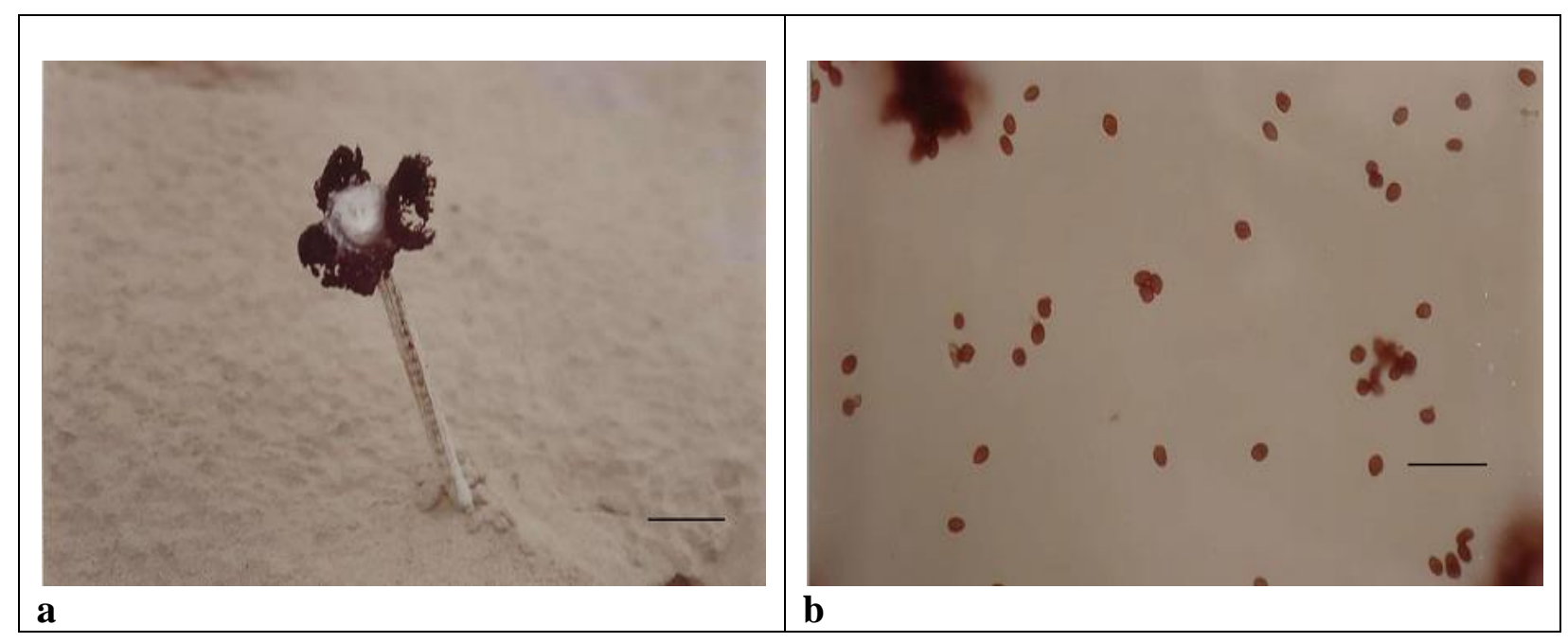

Fig. 8 - a Fruiting body of Montagnea haussknechtii on sand dunes in extreme desiccating conditions. b Spores. Scale bars: $\mathrm{a}=5 \mathrm{~cm}, \mathrm{~b}=20 \mu \mathrm{m}$.

Tulostoma brumale Pers., Neues Magazinfür die Botanik 1: 86 (1794)

Fig. 9

Index Fungorum Number: IF139867; Facesoffungi number: FoF09752

Fruiting body $-1.0-2.0 \mathrm{~cm}$ diameter, Stipe - length $2-4 \times 2.5-1.0 \mathrm{~cm}$ diameter characterized by small, pale grey-brown, more or less rounded head surrounding a tough brown curved stipe, found in small trooping groups in sandy soil and on sand dunes. Peridium - sub-spherical with a small papillate projection, ostiole in the centre of the sub-globose head. Exoperidium - vanishing, soon exposing papery endoperidium. Gleba - at first white and firm, soon becoming brown, turning to a powdery mass of spores which are released from the ostiole. Spores - yellowish-brown, smooth to finely warty, globose, $3.5-5.0 \mu \mathrm{m}$, epispore somewhat dark ferruginous.

Ecology and distribution - Karadelev \& Rusevska (2009) reported Tulostoma brumale from Republic of Macedonia as a psammophilous or humicolous species and in areas with vegetation protection, or on sandy soils amongst herbs and mosses, either solitary or in large numbers. According to Jeppson et al. (2017), this species occurs in all types of sandy and calcareous grasslands, 
sand dunes and steppe vegetation, as well as on moss covered rocks and stone walls in the dry, arid areas of southern and east central Europe.

Specimens examined - JNV/Mycl/128 on 22 July 2019 in zone IA and IIB in sandy soil, collected by Reenu Chouhan. $25^{\circ} 45^{\prime} 0.00^{\prime \prime} \mathrm{N} 71^{\circ} 22^{\prime} 48.00^{\prime \prime} E$ Barmer, elevation: $227 \mathrm{~m}$ (745 ft), 2801'3.43"N73¹8'53.82"E Bikaner, elevation: $242 \mathrm{~m}(794 \mathrm{ft}), 26^{\circ} 55^{\prime} 3.47 " \mathrm{~N} 70^{\circ} 54^{\prime} 13.93 " \mathrm{E}$ Jaisalmer, elevation: $225 \mathrm{~m}(738 \mathrm{ft}), 28^{\circ} 18^{\prime} 0.00^{\prime \prime N 74}{ }^{\circ} 57^{\prime} 0.00^{\prime \prime E}$ Churu, elevation: $292 \mathrm{~m}(958 \mathrm{ft})$,

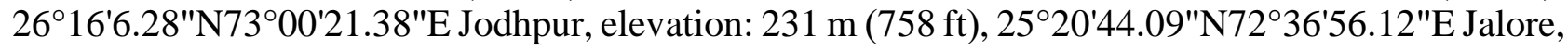

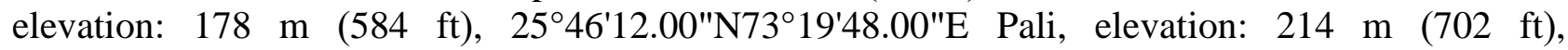

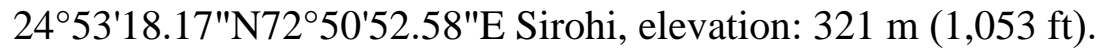

Note - The taxonomic description of this species has been given by Wright (1987) and by Doshi \& Sharma (1997) from Rajasthan. According to Dutta et al. (2020), Tulostoma brumale is morphologically related taxa of Tulostoma squamosum. Accordingly, T. brumale has light brownish to cinereous brown exoperidium, shorter stalks measuring $14-45 \times 1.5-4.0 \mathrm{~mm}$, coloured straw yellow and has smaller spores with a mean diameter of $5 \mu \mathrm{m}$ when compared to the greyish-orange thin exoperidium. This species has a larger size of stalk and comparatively larger spores of size 6.5$7.2 \mu \mathrm{m}$ of $T$. squamosum.

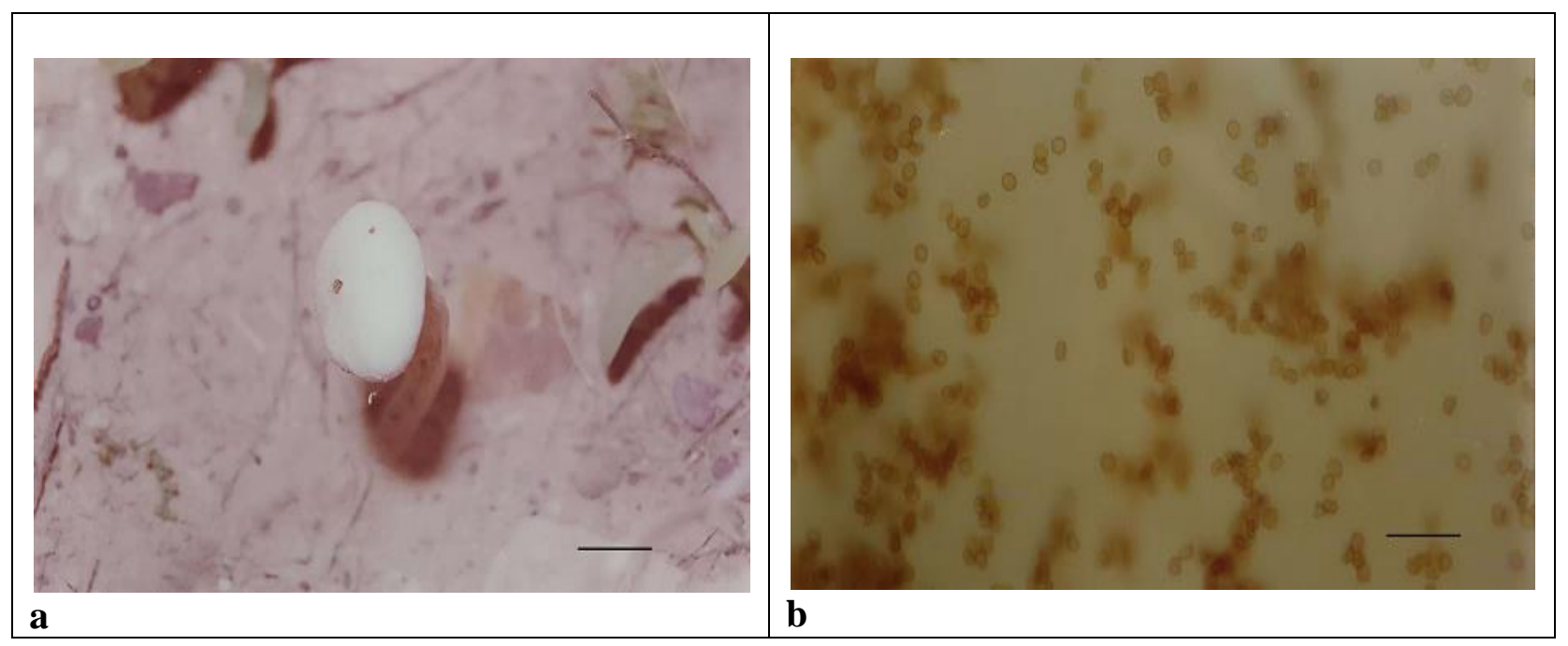

Fig. 9 - a Fruiting body of Tulostoma brumale on dry, sandy soil. b Spores. Scale bar: a $=5 \mathrm{~cm}$, $\mathrm{b}=20 \mu \mathrm{m}$.

\section{Ethanobotanical information}

Podaxis pistillaris and Phellorinia herculeana subsp. herculeana are edible mushrooms consumed by the local people of Rajasthan. These are collected during monsoon season from the sand dunes of Thar Desert and are popular amongst the local people for their good taste and flavor and also sold in the local markets. These mushrooms are known for their nutritional and medicinal properties amongst the rural people (Gupta \& Singh 1991). Sometimes, these are used as bandage of broken bones by the aborigines to darken the white hair in the whiskers of old men, for body painting and as a fly repellent in Australia (Cleland \& Johnston 1933).

\section{Discussion}

During the present investigation, many gasteroid fungi have been reported herein, reflecting the rich fungal biodiversity of the arid and semi-arid areas of the Thar Desert of Rajasthan, surviving under harsh climatic conditions.

Phellorinia herculeana subsp. herculeana and P. herculeana subsp. strobilina represent the wild, edible and medicinal form of gasteroid fungi which are amongst the most abundant gasteroid fungi appearing in the sand dunes and sandy places of the survey area. 
Podaxis pistillaris, $P$. africana, $P$. saharianus and $P$. beringamensis have also been reported herein. These gasteroid fungi are also restricted to arid and semi-arid areas of the Thar Desert and their morphological characterization with thick peridium, increased quantities of spores in desiccating conditions and thick stipe in termite nest- associated species is an adaptation to provide additional support as fruiting body emerges through the termite nests. This study revealed that they are species adapted to survival in desert environment and also reflect the rich mycoflora of the State.

Montagnea haussknechtii and Tulostoma brumale emerges through the surface of sandy soils during evening hours and fully developed fruiting bodies are ready to face the extremities of dry deserts by early morning. These species complete their spore development before stipe extension and immediately disseminate dark, thick walled spores in dry desiccating winds.

The study concludes that the ubiquitous nature of these macrofungi in the Thar Desert of Rajasthan makes them an important part of the ecosystem while taking effective advantage from the minimum inputs of infrequent and unpredictable moisture from rainfall.

\section{Acknowledgement}

The authors thank Dr. Swarnjeet Kaur for her consistent guidance and support.

\section{Conflict of Interests}

The authors declare there are no conflicts of interest.

\section{References}

Ahmad S. 1939 - Higher Fungi of the Punjab plains. I: The Gasteromycetes. Journal of the Indian Botanical Society.18: 47-53.

Ahmad S. 1952 - Gasteromycetes of West Pakistan. Punjab University Press. Lahore.

Al-Fatimi MA, Julich WD, Jansen R, Lindequist U. 2006 - Bioactive components of the traditionary used mushroom Podaxispistillaris. eCAM. 3: 87-92.

Baseia IG, Galvao TC. 2002 - Some interesting Gasteromycetes (Basidiomycota) in dry areas from Northeastern Brazil. Acta Bot Bras 16: 1-9

Baseia IG, Milanez AI. 2002 - Montagneahaussknechtii Rab. (Podaxales) A rare agaricoid fungus: First record from Brazil Acta bot. bras. 16(3): 311-315.

Bohra B, Doshi A, Sharma SS. 2001 - Ecological and geographical distribution of Phelloriniainquinans in Rajasthan and Gujrat. J. Mycol. Pl. Pathol, 31: 373-376.

Bottomley AM. 1948 - Gasteromycetes of South Africa. Bothalia (4): 473-810.

Chouhan R, Kaur S, Gehlot P. 2010 - Some new records of mushroom from India. J. Mycol. P1 Pathol 40(4):550-554.

Cleland JB, Johnston TH. 1933 - The ecology of the Aborigines of central Australia: botanical notes.

Conlon BH, De Beer ZW, De Fine Licht HH, Aanen DK, Poulsen M. 2016 - Phylogenetic analyses of Podaxis specimens from Southern Africa reveal hidden diversity and new insights into associations with termites. Fungal biology (120): 1065-1076.

Conlon BH, Aanen DK, Beemelmanns C, Wilhelm de Beer Z et al. 2019 - Reviewing the taxonomy of Podaxis: Opportunities for understanding extreme fungal lifestyles. Fungal Biology. 123(3): 183-187. Doi 10.1016/j.funbio.2019.01.001

De Villiers JJR, Eicker A, Vander Westhuizen GCA. 1989 - A new section and two new species of Podaxis (Gasteromycetes) from South Africa. South African Journal of Botany (55): 159-164.

Doidge EM. 1950 - The South African fungi and lichens to the end of 1945. Bothalia 5.

Doshi A, Sharma SS. 1997 - Wild mushrooms of Rajasthan. In: Rai RD, Dhar BL, Verm RN (eds). Advances in Mushroom Biology and Production. Mushroom Society of India, National Research Centre for Mushroom, Solan, Chambaghat (HP), India. pp. 105-127.

Dring DM. 1964 - Gasteromycetes of West tropical Africa. Mycological Papers 98: 1-60.

Dring DM, Rayner RW. 1967 - Some Gasteromycetes from eastern Africa. Journal of the East Africa Natural History Society 26: 5-46 
Dutta AK, Paloi S, Acharya K. 2020 - New record of Tulostomasquamosum (Agaricales: Basidiomycota) from India based on morphological features and phylogenetic analysis. Journal of Threatened Taxa 12(3): 15375-15381

Fuhrer B. 2005 - A field guide to Australian fungi. Blooming Books Pvt. Ltd. Science. 360 p.

Gay FJ. 1970 - Isoptera. In 'The Insects of Australia'. (Ed. CSIRO.). pp. 275-293. (CSIRO: Melbourne.)

Gupta S, Singh SP. 1991 - Nutritive value of mushroom Podaxispistillaris. Indian Journal Mycology Plant Pathology, (21): 273-276.

Hashem AR, Al-Rahmah AN. 1993 - Growth of Podaxispistillaris collected from Saudi Arabia at different concentrations of Cadmium and lead. J King Saud Univ 5: 127-135.

Heim R. 1939 - Observations sur la floremycologique Malagache. Boletim da Sociedade Broteriana $13,45-68$.

Heim R. 1977 - Termites et champignons; les champignons termitophilesd' Afrique noire et d' Asiemeridionale. Centre National de la Recherche Scientifique, Paris, France.

Hennings P. 1901 - Fungi Indiae Orientaliis. II. Hedwigia 40: 323-342.

Jacobson KM. 1996 - Fungal ecology in the Etosha National Park. Madoqua. 20(1): 149-155.

Jayasiri SC, Hyde KD, Ariyawansa HA, Bhat J et al. 2015 - The faces of fungi database: fungal names linked with morphology, phylogeny and human impacts. Fungal Diversity 74, 3-18.

Jeppson M, Altés A, Moreno G, Nilsson RH et al. 2017 - Unexpected high species diversity among European stalked puffballs - a contribution to the phylogeny and taxonomy of the genus Tulostoma (Agaricales). MycoKeys 21: 33-88. Doi 10.3897/mycokeys.21.12176

Karadelev M, Rusevska K. 2009 - Diversity and ecology of the genus Tulostoma in the Republic of Macedonia.

Kreisel H, Fatimi MA. 2004 - Basidiomycetes and larger Ascomycetes from Yemen. Feddes Repertorium 115(7-8): 547-561. Doi 10.1002/fedr.200411053

Linnaeus C. 1771 - Mantissa plantarumalteragenerumeditionis VI etspecierumeditionis II. Laurentii Salvii.

Manikandan K, Sharma VP, Kumar S, Kamal S, Shirur M. 2011 - Edaphic conditions of natural sites of Morchella and Phellorinia. Mushroom Research, 20: 117-20.

Martin E, Coronades M, Sanchez A, Perez-Silva E, Herrera T. 2005 - Macromycetes of Pinacate and Great Altar desert biosphere, Sonoron, Mexico. Mycotaxon 95: 31-90.

Moreno G, Mornand J. 1997 - Podaxissaharianus sp. nov. (Podaxales, Gasteromycetes), espèce nouvelle du Maroc. Cryptogamie. Mycologie 18, 247-254.

Morse EE. 1933 - A study of the genus Podaxis. Mycologia 25, 1-33.

Mridu, Atri NS. 2015 - Podaxispistillaris - A common wild edible mushroom from Haryana (India) and its Sociobiology. Kavaka 44: 34-37

Muhsin TM, Abass AF, Al-Habeeb EK. 2012 - Podaxispistillaris (Gasteromycetes) from the desert of southern Iraq, an addition to the known mycota of Iraq. Journal of Basrah Researches (Sciences). (38) 29-35.

Panwar C, Purohit DK. 2002 - Antimicrobial activities of Podaxispistillaris and Phelloriniainquinans against Pseudomonas aeruginosa and Proteus mirabilis. Mushroom Research (1): 43-44.

PanwarC, Parihar R, Purohit DK. 2002 - Antifungal effect of the mushroom, Podaxispistillarison Aspergillus niger Mushroom Research 11(1): 48.

Patel US, Tiwari AK. 2012 - Podaxispistillaris reported from Madhya Pradesh, India. Indian Journal of Fundamental and Applied Life Sciences. 2(1)233-239.

Patil BD, Jadhav SW, Sathe AV. 1995 - Mushroom flora of Maharashtra. Advances in Horticulture - Mushroom - Vol. 13 (Eds: Chadha, K.L. and Sharma, S.R). Malhotra Publishing House, New Delhi, India, pp. 317-328.

Priest M, Lenz M. 1999 - The genus Podaxis (Gasteromycetes) in Australia with description of a new species from termite mounds. Australian Systematic Botany 12: 109-116.

Reid DA, Eicker A. 1991 - A taxonomic survey of the genus Montagnea (Gasteromycetes) with special reference to South Africa. S. Afr. J. Bot. 57(3). 
Sharma VP, Singh M, Kumar S, Kamal S, Singh R. 2015 - Phylogeny and Physiology of Phellorinia spp.: A Delicacy of Indian Desert. International Research Journal of Natural and Applied Sciences: 2(4)1-17.

Sharp C, Piearce G. 1999 - Some Interesting Gasteroid Fungi from Zimbabwe. Kew Bulletin, 54(3), 739-746. Doi 10.2307/4110870

Singer R. 1986 - The Agaricales in Modern Taxonomy. 4th edn. Koeltz Scientific Books, Koenigstein.

Thind KS, Thind IPS. 1982 - The Gasteromycetes of the Himalayas - I Kavaka. 10: 35-45.

Vilgalys R, Hopple J, Hibbett DS. 1993 - Phylogenetic Implications of Genetic Concepts in Fungal Taxonomy: The Impact of Molecular Systematic Studies. Mycology Helvetica 6: 73-91.

Williams JE, Woinarski J. 1997 - Eucalypt ecology: individuals to ecosystems. Cambridge University Press. United Kingdom.

Wright JE. 1987 - The genus Tulostoma (Gasteromycetes): a world monograph. Bibliotheca. Mycologia. 113: 1-338. 